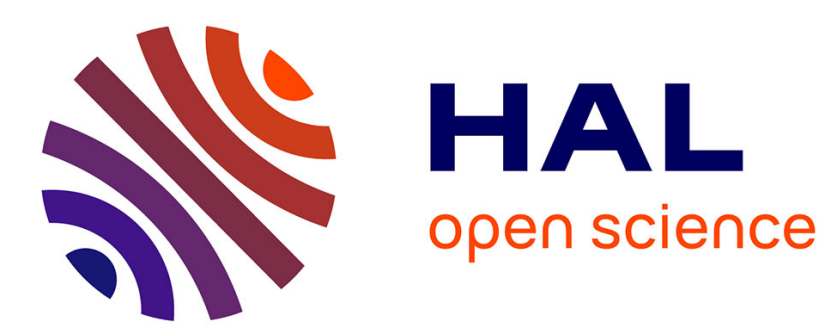

\title{
Bank market power, economic growth and financial stability: Evidence from Asian banks
}

Wahyoe Soedarmono, Fouad Machrouh, Amine Tarazi

\section{To cite this version:}

Wahyoe Soedarmono, Fouad Machrouh, Amine Tarazi. Bank market power, economic growth and financial stability: Evidence from Asian banks. Journal of Asian Economics, 2011, 22, pp.460 - 470. 10.1016/j.asieco.2011.08.003 . hal-01098998

\section{HAL Id: hal-01098998 https://hal.science/hal-01098998}

Submitted on 30 Dec 2014

HAL is a multi-disciplinary open access archive for the deposit and dissemination of scientific research documents, whether they are published or not. The documents may come from teaching and research institutions in France or abroad, or from public or private research centers.
L'archive ouverte pluridisciplinaire HAL, est destinée au dépôt et à la diffusion de documents scientifiques de niveau recherche, publiés ou non, émanant des établissements d'enseignement et de recherche français ou étrangers, des laboratoires publics ou privés. 


\title{
Bank Market Power, Economic Growth and Financial Stability: Evidence from Asian Banks
}

\author{
Wahyoe Soedarmono ${ }^{1}$, Fouad Machrouh ${ }^{1,2}$, Amine Tarazi ${ }^{1, *}$ \\ ${ }^{1}$ Université de Limoges, LAPE, 5 rue Félix Eboué, BP.3127, 87031 Limoges, France \\ ${ }^{2}$ Institut Supérieur de Commerce et d'Administration des Enterprises \\ Km 9.5 Route Nouasseur, BP 8114, Casablanca, Oasis, Morocco
}

\begin{abstract}
This paper examines whether Asian banks are still prone to moral hazard in the aftermath of the 1997 Asian crisis. Using a sample of commercial banks from 12 Asian countries during the 2001-2007 period, our empirical findings highlight that higher market power in the banking market results in higher instability. Although banks are better capitalized in less competitive markets their default risk remains higher. A deeper investigation however shows that such a behaviour is dependent on the economic environment. Higher economic growth contributes to neutralize higher risk taking and higher instability in less competitive markets.
\end{abstract}

JEL: G21, G28, L11

Keywords: Market Power, Financial Fragility, Economic Growth, Asian Banks

\footnotetext{
* Corresponding author. Tel: (+33) 5551492 36. Fax: (+33) 555149211.

E-mail addresses: wahyoe.soedarmono@unilim.fr (W.Soedarmono), fouad.machrouh @unilim.fr (F.Machrouh), amine.tarazi@unilim.fr(A.Tarazi).
} 


\section{Introduction}

The 1997 Asian financial crisis has raised concerns regarding the stability of financial systems in Asian countries. Unlike the previous crises characterized by a failure of government macroeconomic policies, the 1997 crisis has cast doubts on the process of uncontrolled financial liberalization and its implications for the economy as a whole. In the Asian context, financial liberalization has indeed resulted in unfettered bank competition on the credit market creating bubbles notably in real estate markets (Sachs and Woo, 2000).

Moreover, the 1997 Asian crisis has also changed the structure of the banking industry and the nature of firms' corporate governance in Asia. In the banking industry, Asian countries have experienced a rapid growth of bank consolidations or mergers and acquisitions (M\&As) that peaked to 25 percent per year as of 2003. Foreign Direct Investment (FDI), notably cross-border M\&As involving banks in emerging countries, also showed an upward trend from US\$ 2.5 billion during 1991-1995 to US\$ 67.5 billion during 2001-2005 (Domanski, 2005; Moshirian, 2008). Asia therefore accounts for 36 percent of total bank M\&As values, the second highest recipient of cross-border bank M\&As after Latin America. Meanwhile, corporate governance reforms have also been implemented to eliminate incentives for imprudent strategies, including excessive short-term borrowing and speculative investments ${ }^{1}$.

With regards to the implications of bank consolidations to rescue distressed banks, Berger and Mester (2003) argue that market power gained by banks after consolidation increases banks' capacity to expand their activity into various products and across national borders. This process has lead to the emergence of large "too big to fail" banks and potentially to higher moral hazard incentives to exploit government bailout. Meanwhile, regarding corporate governance reforms in Asia, firms still face major challenges, such as poor accounting systems, non-transparent management, and weak protection for minority shareholders (Park, 2006). Because firms significantly depend on banks for their external funding (Adams, 2008), bank stability is a major concern for policy makers. Corporate sector vulnerability is indeed more likely to affect bank soundness through risk-shifting mechanisms in bank-based financial systems (Stiglitz and Weiss, 1981).

In spite of the importance of such contemporary trends, few studies focus on the financial stability implications of bank consolidation in the Asian context. This paper contributes to fulfil this gap using a sample of commercial banks from 12 Asian countries that

\footnotetext{
${ }^{1}$ See Cook (2009) for deeper insights on the corporate governance reforms in various Asian countries.
} 
have been affected by the 1997/1998 Asian crisis (China, Hong-Kong, India, Indonesia, Pakistan, Philippines, South Korea, Sri Lanka, Thailand, Taiwan, Thailand, and Vietnam). Specifically, we assess the link between market power in the banking industry and financial stability, as bank consolidations in the aftermath of the 1997 Asian crisis can influence the degree of competition or market power in the banking industry. We work on a sample covering the 2001-2007 period and focus on the role of the economic environment, where we investigate the link between bank instability and market power using various risk measures and by taking economic growth into consideration.

The rest of this paper is structured as follows. Section 2 provides a brief literature review on the nexus between bank market power and financial stability and discusses our research focus. Section 3 presents our data, variables and descriptive statistics. Section 4 highlights our econometric specification and methodology. Section 5 discusses our empirical findings, while Section 6 provides some sensitivity analyses. Section 7 concludes the paper.

\section{Bank market power and financial stability}

Research on the link between bank competition and financial stability remains inconclusive. In the U.S. banking industry, Keeley (1990) is the first to document that greater bank competition following financial deregulation in the late eighties has encouraged banks to take on more risk, as bank charter value declined. Demsetz et al. (1996) support such findings in the U.S banking industry, where banks with higher market power exhibit higher solvency ratios and lower asset risk. Bofondi and Ghobi (2004) examine such a relationship for Italian banks and find that the loan default rate is positively associated to the number of banks operating in the industry. Jimenez et al. (2008) also find a negative impact of the Lerner index on risk-taking in Spanish banks. In a cross-country setting, Levy-Yeyati and Micco (2007) document that competition in banking erodes bank stability in Latin America. Yet, Beck et al. (2006) examine the effect of bank concentration on the probability of banking crises instead of considering bank risk taking issues. Working on 69 countries during the 1980-1997 period, their empirical results highlight that countries with less competitive banking systems are less prone to banking crisis than the ones with greater bank competition. To sum up, the positive link between bank market power and financial stability is known as the "charter value" hypothesis in the literature.

Conversely, Boyd and De Nicolo (2005) develop an alternative view on the link between bank market power and financial stability, which is often referred to as the "competition-stability" hypothesis. By considering competition in both deposit and loan 
markets, higher market power in the deposit market will drive banks to increase their loan interest rate. Such bank behaviour raises entrepreneurial moral hazard which in turn increases banks' default risk through risk-shifting mechanisms following Stiglitz and Weiss (1981). Boyd et al. (2006) further provide empirical evidence for the "competition-stability hypothesis" based on US data. Uhde and Heimeshoff (2009) also support the competitionstability hypothesis using European data. Moreover, they also show that the concentrationfragility nexus is more likely to occur in the less developed countries of Eastern Europe.

In the meantime, some studies also consider bank capital ratios in the relationship between bank competition and financial stability. Schaeck and Cihák (2007) document that a competitive banking market drives banks to hold higher capital ratios to preserve their competitive advantages on their peers. On the contrary, Berger et al. (2009) show that higher bank market power enhances bank capitalization. Furthermore, their empirical results suggest that although higher bank market power increases non-performing loans, such trends are associated with a decrease in bank default risk. This is because the levels of capitalization in banks with higher market power are sufficient to cover an increase in banks' non-performing loans and hence, bank stability is not affected.

Our paper builds on the work of Berger et al. (2009), Uhde and Heimeshoff (2009), Schaeck and Cihák (2007), and Soedarmono et al. (2011), and extends it in other directions. First, Berger et al. (2009) estimate the degree of bank-level market power, while our paper estimates the degree of market power for the whole banking system in order to account for bank consolidation trends that may change the degree of competition in the banking market. In this aspect, our conception of bank consolidation is close to Uhde and Heimeshoff (2009). However, we do not consider the implication of bank consolidations through the bank concentration channel as in Uhde and Heimeshoff (2009), but through the degree of market power in the banking market ${ }^{2}$. Second, we focus on the impact of bank competition on bank capitalization, insolvency risk and risk taking measured by the volatility of returns rather than the extent of non-performing loans. Risk taking refers to an ex-ante action while a risk measure based on non-performing loans indicates an ex-post condition. To prevent the excessive accumulation of non-performing loans that may contribute to the occurrence of a financial crisis, raising concerns on bank moral hazard that leads to excessive risk taking is an important dimension. Third, we also consider the influence of macroeconomic performance

\footnotetext{
${ }^{2}$ DeYoung et al (2009) provide a comprehensive discussion on the link between consolidation and market power in banking.
} 
on the nexus between bank competition and financial stability following Schaeck and Cihák (2007).

Schaeck and Cihák (2007) analyze the impact of country-level per capita income on the link between bank competition and the capital ratio, while we focus on the role of economic growth in the competition-stability nexus in banking. In this sense our work is also related to the literature on the procyclicality of bank capital buffer, showing that banks hold lower capital as economic growth increases (Ayuso et al, 2004; Jokipii and Milne, 2008). Hence, higher economic expansion could therefore affect the impact of bank competition on capital ratios that in turn could influence bank income volatility and insolvency risk ${ }^{3}$. Our paper follows and adds to Soedarmono et al. (2011) who investigate the competition-stability nexus for Asian banks showing that higher market power is associated with higher instability except during the 1997 financial crisis period. In their setting they do not consider the role played by economic growth in the risk taking implications of the degree of bank competition.

\section{Data sources, variables and descriptive statistics}

\subsection{Data sources}

Our data come from several sources and consist of bank-specific and country-specific data. For bank-specific data, we start by taking from BankScope Fitch-IBCA a set of annual series for the 1999-2007 period. We consider commercial banks in 12 Asian countries. These include China (137) ${ }^{4}$, Hong Kong (53), India (74), Indonesia (80), Malaysia (51), Pakistan (30), Philippines (41), South Korea (21), Sri Lanka (14), Taiwan (49), Thailand (23), and Vietnam (34). Our bank sample consists of 607 commercial banks. For country-specific data, we use several datasets such as the International Financial Statistics from the International Monetary Fund, the Financial Structure database from Beck and Demirgüç-Kunt (2009), the Governance Indicator index from Kaufmann et al (2008), and the Economic Freedom index from Heritage Foundation.

\subsection{Bank Market Power}

Claessens and Laeven (2004) argue that bank performance measures do not appropriately indicate the degree of bank market power because such measures can be

\footnotetext{
${ }^{3}$ The issue of procyclicality of bank capital is beyond the scope of this paper but taking into account the role of economic growth in the link between market power and bank stability is an important dimension. As higher economic growth improves borrowers' financial health, it might also enable banks to increase their profitability without undertaking excessive risk.

${ }^{4}$ The values in parentheses represent the number of banks obtained.
} 
affected by various bank-level and country-level characteristics. Therefore, the degree of bank competition should be determined endogenously. In a similar vein, Beck (2008) highlights that using measures of bank market structure and concentration ratios to assess the degree of bank market power is inappropriate, since such measures do not account for differences in bank strategies. Consequently, such indicators merely indicate the actual market share of each bank. They do not necessarily measure bank competition captured by the degree of bank market power.

Meanwhile, the use of the H-statistic developed by Panzar and Rosse (1987) can be an alternative method to infer the degree of market power in the banking industry (Claessens and Laeven, 2004; Molyneux and Nguyen-Linh, 2008). Nevertheless, a critical feature of the H statistic is that the Panzar-Rosse approach must be applied on the basis of observations that are in long-run equilibrium (Bikker and Bos, 2008). An equilibrium test needs to be conducted by equalizing adjusted rates of return across banks. At equilibrium, the rates of return will not be correlated with input prices. When the equilibrium test is rejected, then the $H$ estimates should be interpreted with great caution, as they may be based on observations from a disequilibrium situation.

For such reasons, we use the new industrial organisation approach following Uchida and Tsutsui (2005), Brissimis et al (2008), and Soedarmono et al. (2011) to quantify the degree of market power in Asian banking. We thereby obtain a more tractable measure of bank competition. The merit of this non-structural measure of bank competition is to provide the estimates of the degree of banking industry market power in each period. Furthermore, this measure does not require any information on the market structure of each bank. Eventually, this method allows us to endogeneously determine the degree of market power in the banking industry. More specifically, we estimate a system of three equations that correspond to a translog cost function, to a revenue function obtained from bank profit maximization, and to an inverse loan demand function. This system is shown in System (1). 


$$
\begin{aligned}
\ln C_{i t}= & b_{0}+b_{1} \overline{\ln q_{i t}}+\frac{1}{2} b_{2}\left(\overline{\ln q_{i t}}\right)^{2}+b_{3} \overline{\ln d_{i t}}+\frac{1}{2} b_{4}\left(\overline{\ln d_{i t}}\right)^{2}+b_{5} \overline{\ln w_{i t}}+\frac{1}{2} b_{6}\left(\overline{\ln w_{i t}}\right)^{2} \\
& +b_{7}\left(\overline{\ln q_{i t}}\right)\left(\overline{\ln w_{i t}}\right)+b_{8}\left(\overline{\ln q_{i t}}\right)\left(\overline{\ln d_{i t}}\right)+b_{9}\left(\overline{\ln d_{i t}}\right)\left(\overline{\ln w_{i t}}\right)+e_{i t}^{c} \\
R_{i t}= & \frac{\theta_{t}}{\eta_{t}} R_{i t}+r_{i t} q_{i t}+c_{i t}\left(b_{1}+b_{2}\left(\overline{\ln q_{i t}}\right)+b_{7}\left(\overline{\ln w_{i t}}\right)+b_{8}\left(\overline{\ln d_{i t}}\right)\right) \\
& +C_{i t} \frac{q_{i t}}{d_{i t}}\left(b_{3}+b_{4}\left(\overline{\ln d_{i t}}\right)+b_{8}\left(\overline{\ln q_{i t}}\right)+b_{9}\left(\overline{\ln w_{i t}}\right)\right)+e_{i t}^{S} \\
\ln p_{i t}= & g_{0}-(1 / \eta) \ln q_{i t}+g_{1} \ln G D P G_{t}+g_{2} \ln \text { OPL } L_{i t}+e_{i t}^{D}
\end{aligned}
$$

In defining revenue, we follow Brissimis et al (2008) using total revenue from both interest and non-interest revenue. This construction allows us to implicitly capture the different strategies followed by banks in shifting part of their activities to non-interest income activities. Considering total revenue also allows us to account for earnings generated by assets other than loans ${ }^{5}$. Variables with bars represent deviations from their cross-sectional means in each time period, where this procedure is to cope with multicollinearity. The degree of market power in the banking industry in each year is given by $\theta_{t} \in[0,1]$ representing the well-known conjectural variations elasticity of total industry outputs with respect to the output of the i-th bank. In the case of perfect competition, $\theta_{t}=0$; under pure monopoly, $\theta_{t}=1$; and finally, $\theta_{t}<0$ implies pricing below marginal cost and could result, for example from a nonoptimizing behavior of banks. In the special case of Cournot competition, $\theta_{i t}$ is simply referred to as the market share of the $\mathrm{i}$-th bank.

Moreover, $C_{i t}$ is defined as total expenses from both interest and non-interest income activities, $q_{i t}$ as total earning assets, $d_{i t}$ as total deposits and short-term funding, $w_{i t}$ as the ratio of operating expenses to total assets, $R_{i t}$ as total revenue, $r_{i t}$ as the ratio of interest expenses to total deposits, and $p_{i t}$ as the ratio of total revenue to total earning assets. Meanwhile, GDPG, and $O P L_{i t}$ are factors that affect demand, defined as the real gross domestic product growth rate, and the ratio of operating expenses to total loans, respectively. Following Brissimis et al (2008) and Soedarmono et al. (2011), System (1) is estimated country by country. To estimate $\theta_{t}$ we use dummy variables for each year, while to estimate $\eta$ we use time dummy variables every two years due to the fact that $\eta$ values are linearly dependent on the time-specific control variable (GDPG).

\footnotetext{
${ }^{5}$ Uchida and Tsutsui (2005) only consider revenue generated by bank loans.
} 


\subsection{Financial stability}

In this paper, financial stability is captured by bank income volatility, insolvency risk and capitalization. In order to measure bank income volatility that reflects bank risk-taking strategies, we use the standard deviation of banks' return on average assets (SDROA) and that of banks' return on average equity (SDROE). SDROA is calculated from the return on average assets $(R O A A)$ values taken from period $t$ to $t-2$ (a three-period rolling window). Analogically, SDORE is calculated from the return on average equity (ROAE) using a threeperiod rolling window. This approach is consistent with Agoraki et al. (2011) ${ }^{6}$.

To account for bank insolvency risk, we use the Z-score method based on ROAA. The Z-score (ZROA) indicates the number of standard deviations that the bank's ROAA has to fall below its expected value before equity is completely exhausted. Thus, higher Z-score is interpreted as a decrease in bank insolvency risk. ZROA is formulated as follows.

$$
\operatorname{ZROA}_{i, t}=\frac{\operatorname{ROAA}_{i, t}+\text { EQTA }_{i, t}}{\text { SDROA }_{i, t}}
$$

EQTA is the ratio of total equity to total assets. For robustness, we also consider the Z-score measure based on ROAE (ZROE) which is formulated as follows.

$$
\operatorname{ZROE}_{i, t}=\frac{\operatorname{ROAE}_{i, t}+1}{\operatorname{SDROE}_{i, t}}
$$

In order to capture the levels of bank capitalization, we use the total risk-based capital ratio $(C A R)$ and the equity to total assets ratio (EQTA). EQTA is essentially a measure of leverage. The use of such a variable is consistent with Blum (2008) who highlights that the leverage ratio can be a tool to discipline bank moral hazard. Meanwhile, CAR is the sum of equity capital and other hybrid capital divided by risk-weighted assets. Repullo (2004) argues that risk-based capital requirements can overcome bank moral hazard in a competitive market.

\subsection{Control variables}

First, we incorporate country-specific control variables. We follow Schaeck and Cihák (2007) by considering the inflation rate (INF) and the real gross domestic product growth rate $(G D P G)$, since macroeconomic developments are likely to affect the quality of banks' assets, as well as the level of bank capitalization.

Second, we also control for bank-specific characteristics. We consider the loan-todeposit ratio $(L D R)$ to capture bank liquidity that may affect bank default probability. We

\footnotetext{
${ }^{6}$ It is worth noting that our study only covers the 2001-2007 period, although our initial sample covers the 19992007 period. This is because our risk indicators are based on a three-year rolling window starting in 2001.
} 
further incorporate the ratio of loan loss reserves to total loans $(L L R)$ to account for credit risk, since credit risk is the major determinant of bank risk and capitalization. In the meantime, Foos et al. (2010) also document that excessive loan growth can result in higher bank risk and lower capital ratios. We thus include the loan growth rate as a control variable. We also control for the differences in technical efficiency following Agoraki et al. (2011) and Boyd et al. (2006). Technical efficiency is captured by the ratio of operating expenses to total assets (OVERHEAD). Bank size can also be a major factor of higher risk taking due to "too big to fail" effects in larger banks (Kane, 2000; Mishkin, 2006). To take into account size effects, we incorporate the logarithm of banks' total average assets (SIZE) in our estimations.

\subsection{Descriptive statistics and the market power index}

Table 1 presents the "clean" descriptive statistics of our variables after imposing several restrictions on our dataset to exclude outliers that may affect our empirical results. Our restrictions are as follows. We exclude the $2.5 \%$ highest values of $L D R, O P L$, $O V E R H E A D, Z R O A$ and $Z R O E$ because these variables have a right-skewed distribution. For OVERHEAD, we further exclude all values that are lower than 0 . To this end, Table 2 shows the values taken by the Lerner index for each country every year.

\section{Econometric model and estimation methodology}

To assess the impact of bank competition on financial stability, we construct the following equation that is consistent with the previous literature (Boyd et al, 2006; Brissimis et al, 2008; Agoraki et al, 2011; Soedarmono et al, 2011).

$$
\begin{aligned}
& \operatorname{STABILITY~}_{i, j, t}=\alpha_{1} \text { LERNER }_{j, t}+\alpha_{2} \operatorname{GDPG}_{j, t}+\alpha_{3} \operatorname{INF}_{j, t}+\alpha_{4} L_{i, j, t}+\alpha_{5} L_{i, j} \\
& +\alpha_{6}{ }_{\text {LOANG }} i_{i, j, t}+\alpha_{7} \text { OVERHEAD }{ }_{i, j, t}+\alpha_{7} \operatorname{SIZE}_{i, j, t}+\varepsilon_{i, t}
\end{aligned}
$$

where $i, j, t$ indicates bank, country, and time index, respectively. Meanwhile, STABILITY represents dependent variables consisting of SDROA, SDROE, ZROA, ZROE, EQTA, and CAR. Moreover, our paper also examines whether the macroeconomic environment influences the nexus between bank competition and financial stability. For this purpose, we specify the following equation.

$$
\begin{aligned}
& \text { STABILITY }{ }_{i, j, t}=\alpha_{1} \text { LERNER }_{j, t}+\alpha_{2} \text { GDPG } \\
& +\alpha_{4, t} \text { INF }_{j, t}+\alpha_{5} \text { LDR }_{i, j, t}+\alpha_{6} \text { LLR }_{i, j, t}+\alpha_{7} \text { LOANG }_{i, j, t}+\alpha_{8} \text { OVERHEAD } \\
& +\alpha_{9} \text { SIZE }_{i, j, t}+\varepsilon_{i, t}
\end{aligned}
$$


To estimate (4) and (5), we run Fixed Effect (FE) regressions to correct for unobservable bank-specific and time-specific characteristics. We also correct for possible heteroskedasticity and autocorrelation problems using the appropriate White coefficient covariance method.

Recent empirical literature further sheds light on endogeneity problems in the nexus between bank competition and financial stability (Berger et al, 2009; Uhde and Hemishoff, 2009; Gonzales, 2005; Schaeck and Cihák, 2007). In order to take this issue into account, we further endogenize the measure of bank competition by specifying instrumental variables. For this purpose, we also estimate (4) and (5) using the Generalized Method of Moments (GMM) with fixed-effect corrections instead of using the Two-Stages Least Squares (2SLS) method as in Uhde and Heimeshoff (2009) and Schaeck and Cihák (2007). In this regard, Hall (2005) shows that the GMM estimation is robust to the distribution of errors. The GMM estimation further accounts for heteroskedasticity and hence, the GMM estimation is more efficient than the 2SLS estimation.

With regards to instrumental variables for LERNER, we consider three macroeconomic variables. These include the ratio of stock market capitalization to GDP (STOCK), the rule of law index $(R L A W)$, and the economic freedom index (ECOFREE). STOCK is retrieved from Beck and Demirgüç-Kunt (2009), while RLAW and ECOFREE are taken from Heritage foundation and Kaufmann et al (2008), respectively.

$S T O C K$ is expected to influence LERNER because higher stock market development can affect the demand for banking services (Schaeck and Cihák, 2007). As the stock market develops, banks will compete with capital markets to preserve bargaining power in the market $^{7}$. Moshirian (2009) also points out that greater minority shareholders' protection helps boosting financial globalization that in turn, affects the degree of competition in the banking market. In order to account for the quality of law enforcement that protects minority shareholders' rights, we consider the rule of law index $(R L A W)$ as one of the instrumental variables for LERNER. Finally, we consider the degree of economic freedom (ECOFREE) as an instrumental variable for LERNER, as greater economic freedom can lead to new investment opportunities. Higher economic freedom is also associated with weaker bank activity restrictions, leading to higher sophistication in banking products that may in turn affect the degree of bank competition.

\footnotetext{
${ }^{7}$ See Boot and Thakor (2000) for further discussions on the bank-capital market competition and the inter-bank competition.
} 
Table 3 shows that such instrumental variables significantly affect the degree of market power in the banking market (LERNER). In the Asian context, greater bank competition is mainly due to stronger protections for minority shareholders represented by the rule of law index $(R L A W)$, while with higher economic freedom and stock market development, banking markets appear to be less competitive.

\section{Empirical findings}

In order to analyze the impact of market power in the banking market on bank risk taking, insolvency risk and capitalization, we proceed in two steps. First, we investigate the link in a general framework. Second, we consider how economic growth influences the link between market power in banking and financial stability, where financial stability refers to bank risk taking, insolvency risk and capital ratios.

Table 4 shows our estimation results from the FE and the GMM regressions. Our results highlight that the degree of market power in the banking market (LERNER) is positively related to bank income volatility as measured by either SDROA or SDROE. Higher LERNER further exacerbates bank insolvency risk (ZROA or ZROE). However, higher LERNER is also associated with an increase in capital ratios (EQTA or CAR).

These findings indicate that although banks in less competitive markets are able to hold higher capital ratios, these levels are not sufficient to cover an increase in bank risk taking that in turn exacerbates bank insolvency risk. More precisely, Equation (2) provides a straightforward intuition on such empirical findings, where the levels of capitalization are insufficient to cover banks' risk-taking. Indeed, we observe that banks in less competitive markets are able to increase their equity to total assets ratio (EQTA). But according to Equation (2), the impact of market power ( $L E R N E R$ ) on bank insolvency risk (ZROA) remains negative as long as LERNER is positively related to bank income volatiltiy (SDROA) and at the same time, a higher value of LERNER increases SDROA more strongly than EQTA. In other words, bank moral hazard in less competitive markets is likely to exist.

Our findings are consistent with Molyneaux and Nguyen-Linh (2008), Agusman et al. (2006), and Soedarmono et al. (2011). Molyneaux and Nguyen-Linh (2008) document that higher bank competition reduces risk taking in Southeast Asian banks, while Agusman et al (2006) point out that higher charter value in publicly-traded banks in Asia fails to alleviate banks' asset risk. Our findings are also consistent with Soedarmono et al (2011), even though they include financial crises periods in their study. 
Our findings do not support the "charter value" hypothesis. More specifically, our findings differ from Ariss (2010) who finds that bank-level market power enhances the stability of banks in developing countries including some countries in Asia. Such different findings can be due to differences in econometric specifications. Ariss (2010) considers a cross-section analysis, while our paper employs panel data methodology that takes into account both time-specific and bank-specific characteristics. The composition of countries used in our study may also explain such differences, since macroeconomic and regulatory environements can influence the link between bank competition and financial stability.

Previous studies have not accounted for the influence of macroeconomic environments on the nexus between bank competition and financial stability. An exception is Schaeck and Cihák (2007) who consider the influence of country-level degree of economic development on the link between bank competition and capital ratios. Their results indicate that higher bank competition as captured by the Panzar-Roose H-statistics tends to alleviate bank capital ratios in countries with higher $G D P$ per capita.

Following Schack and Cihák (2007), we further investigate whether the macroeconomic environment affects the impact of bank competition on bank risk taking, insolvency risk and capital ratios. However, in our study we consider the influence of economic growth instead of country-level economic development used by Schaeck and Cihák (2007). Our sample consists of developing countries with presumably relatively more homogeneous economic development levels. More specifically, we follow the steps of Soedarmono et al. (2011) who consider the same sample of countries to investigate the impact of financial crises on the link between bank competition and risk. In the present study, we focus on the period following the 1997/1998 Asian crisis and extend their approach by introducing the effect of economic growth on the competition-stability nexus.

Table 5 shows our estimation results when we augment our model by introducing the interaction term between $L E R N E R$ and GDPG as an explanatory variable. Following Schaeck and Cihák (2007) as well, $L E R N E R^{*} G D P G$ is treated as an endogenous variable. Our empirical results show that higher economic growth brings banks in less competitive markets to reduce bank risk taking (SDROA and SDROE), overcome insolvency risk (ZROA and $Z R O E)$ and increase the equity to total asset ratio $(E Q T A)^{8}$.

\footnotetext{
${ }^{8}$ Although $L E R N E R^{*} G D P G$ is negatively related to the total risk-based capital ratio $(C A R)$, this result does not change the overall intuition with regard to the impact of economic growth on the link between bank competition and financial stability. As higher economic growth drives banks in less competitive market to reduce bank total risk-based capital ratio, such banks obviously tend to exhibit higher insolvency risks.
} 


\section{Sensitivity analyses}

To check for robustness, we perform several sensitivity analyses in our paper ${ }^{9}$. First, we modify the inverse loan demand function (the third equation) as shown in System (1) by including the logarithm of total assets $(S I Z E)$ as a control variable that influences the pricing of banking products. Using this different specification, the empirical findings discussed in Section 5 are not altered. Second, we also control for bank income diversification, since noninterest income can affect bank stability (Lepetit et al, 2008). Considering the ratio of noninterest income to total gross revenue $(N N I)$ as a control variable does not change our main findings. Third, we further control for the macroeconomic environment by incorporating the ratio of the five largest banks' total assets to the banking system's total assets (CFIVE) following Schaeck and Cihák (2007). Our main findings remain the same. Fourth, we exclude the year 2007 from our sample to isolate the impact of the 2007/2008 financial crisis. The link between bank competition and financial stability is not altered.

\section{Conclusion}

The process of bank consolidation is one of the major trends in Asian banking systems in the aftermath of the 1997 financial crisis. As bank consolidations tend to specifically affect the degree of bank competition in emerging and developing countries (Jeon et al, 2011), this paper examines the link between bank competition and financial stability in the Asian context, particularly in the post-1997 crisis period.

Using a sample of commercial banks in 12 Asian countries over the 2001-2007 period, our empirical findings indicate that higher market power in the banking industry is associated with better capital adequacy. However, the higher level of bank capitalization in less competitive markets is not sufficient to cope with bank moral hazard that induces excessive risk taking and exacerbates bank insolvency risk. Nevertheless, our findings also indicate that stronger economic growth mitigates higher risk taking behaviour and higher bank instability in less competitive markets.

On the whole, in the aftermath of the 1997 Asian crisis, Asian banks in general still seem to suffer from moral hazard. Higher market power in banking that is expected to enhance banks' self-discipline still fails to moderate high risk taking strategies. Nevertheless, such problems are less likely to occur in expansionary economic environments.

\footnotetext{
${ }^{9}$ The results from these sensitivity analyses are not shown in the paper but are available upon request.
} 


\section{References}

Adams, C. (2008). Emerging East Asian banking system: Ten years after the 1997/98 crisis. ADB Working Paper Series on Regional Economic Integration, 16

Agoraki, M.K., Delis, M.D., \& Pasiouras, F. (2011). Regulations, competition and bank risk taking in transition countries. Journal of Financial Stability, 7(1), 38-48

Agusman, A., Gasbarro, D., \& Zumwalt, J.K. (2006). Bank moral hazard and the disciplining factors of risk taking: evidence from Asian banks during 1998 - 2003. Working Paper, FMA European Conference, Stockholm

Ariss, R.T. (2010). On the implications of market power in banking: Evidence from developing coutnries. Journal of Banking and Finance, 34 (4), 765-775

Ayuso, J., Perez, D., \& Saurina, J. (2004). Are capital buffers pro-cyclical? Evidence from Spanish panel data. Journal of Financial Intermediation, 13, 249-264

Beck, T., Dermirguc-Kunt, A., \& Levine, R. (2006). Bank concentration, competition and crises: First results. Journal of Banking and Finance, 30, 1581-1603

Beck, T. (2008). Bank competition and financial stability: friends or foes? World Bank Policy Research Working Paper, 4656

Beck, T., \& Demirgüç-Kunt, A. (2009). Financial Institutions and Markets Across Countries and over Time: Data and Analysis. World Bank Policy Research Working Paper, 4943

Berger, A.N., Klapper, L.F., \& Ariss, R.T. (2009). Bank competition and financial stability. Journal of Financial Services Research, 35, 99-118

Berger, A., \& Mester, L. (2003). Explaining the dramatic changes in performance of US banks: Technological change, deregulation, and dynamics changes in competition. Journal of Financial Intermediation, 12, 57-95

Bikker, J.A., \& Bos, J.W.B. (2008). Bank performance: A theoretical and empirical framework for the analysis of profitability, competition and efficiency. Routledge International Studies in Money and Banking, New York

Blum, J.M. (2008). Why Basel II may need a leverage ratio restriction. Journal of Banking and Finance, 32, 1699-1707

Bofondi, M., \& Gobbi, G. (2004). Bad loans and entry into local credit markets. Bank of Italy, Working Paper, 509

Boyd, J.H., \& De Nicolo, G. (2005). The theory of bank risk taking and competition revisited. Journal of Finance, 60, 1329-1343

Boyd, J.H., De Nicolo, G., \& Jalal, A.M., 2006. Bank risk-taking and competition revisited: new theory and new evidence. IMF Working Paper, 06/297 
Brissimis, S.N., Delis, M.D., \& Papanikolaou, N.I. (2008). Exploring the nexus between banking sector reform and performance: Evidence from newly acceded EU countries. Journal of Banking and Finance, 32, 2674-2683

Claessens, S., \& Laeven, L. (2004). What drives bank competition? Some international evidence. Journal of Money, Credit and Banking, 36, 563-583

Cook, M. (2009). Banking sector reform in South East Asia: The region's decisive decade. Routledge Taylor and Francis Group, New York

Demsetz, R.S., Saidenberg, M.R., \& Strahan, P.E. (1996). Banks with something to lose: the disciplinary role of franchise value. Economic Policy Review, 1-14

DeYoung, R., Evanoff, D., \& Molyneux, P. (2009). Mergers and acquisitions of financial institutions: A review of the post-2000 literature. Journal of Financial Services Research, 36, $87-110$

Domanski, D. (2005). Foreign banks in emerging economies: Changing players changing issues. BIS Quarterly Review, 69-81

Foos, D. (2010). Loan growth and riskiness of banks. Journal of Banking and Finance, 34(12), 2929-2940

Gonzales, F. (2005). Bank regulation and risk-taking incentives: an international comparison of bank risk. Journal of Banking and Finance, 29(5), 1153-1184

Hall, A.R. (2005). Generalized method of moments. Oxford University Press, Oxford

Jeon, B.N., Olivero, M.P., \& Wu, J. (2011). Do foreign banks increase competition? Evidence from emerging Asian and Latin American banking markets. Journal of Banking and Finance, $35,856-875$

Jimenez, G., Lopez, J.A., \& Saurina, J. (2008). How does competition impact bank risk taking. Working Paper, Bank of Spain

Jokipii, T., \& Milne, A. (2008). The cyclical behaviour of European bank capital buffers. Journal of Banking and Finance, 32, 1440-1451

Kane, E.J. (2000). Incentives for banking megamergers: What motives might regulators infer from event-study evidence? Journal of Money, Credit and Banking, 32, 671-701

Kaufmann, D., Kraay, A., \& Mastruzzi, M. (20080. Governance Matters VII : Aggregate and Individual Governance Indicators 1996-2007. World Bank Policy Research Working Paper, 4654

Keeley, M.C., (1990). Deposit insurance, risk and market power in banking. American Economic Review, 80(5), 1183-1200

Mishkin, F.S. (2006). How big a problem is too big to fail? Journal of Economic Literature, 44, 988-1004 
Molyneux, P., \& Nguyen-Linh, H. (2008). Competition and risk in the South East Asian banking. Working Paper, University of Bangor

Moshirian, F. (2009). Can Asia Pacific Community similar to the European Community emerge? Journal of Banking and Finance, 33, 2-8

Moshirian, F. (2008). Financial services in an increasingly integrated global financial market. Journal of Banking and Finance, 32 (11), 2288-2292

Lepetit, L., Nys, E., Rous, P., \& Tarazi, A. (2008). Bank income structure and risk: An empirical analysis of European banks. Journal of Banking and Finance, 32, 1452-1467

Levy-Yeyati, E., \& Micco, A. (2007). Concentration and foreign penetration in Latin American banking sectors: Impact on competition and risk. Journal of Banking and Finance, $31,1633-1647$

Panzar, J.C., \& Rosse, J.N. (1987). Testing for 'monopoly' equilibrium. Journal of Industrial Economics, 35 (4), 443-456

Park, Y.C. (2006). Economic liberalisation and integration in East Asia: A post-crisis paradigm. Oxford University Press

Repullo, R. (2004). Capital requirements, market power, and risk-taking in banking. Journal of Financial Intermediation, 13, 156-182

Sachs, J., \& Woo, W.T. (2000). Understanding the Asian financial crisis. In : J. D. Sachs \& K. Schwab (Eds.), The Asian financial crisis: Lessons for a resilient Asia. MIT Press

Schaeck, K., \& Cihák, M. (2007). Banking competition and capital ratios. IMF Working Paper, 07/216

Soedarmono, W., Machrouh, F., \& Tarazi, A. (2011). Bank Competition, Risk and Capital Ratio: Evidence from Asia. Working Paper, Université de Limoges, LAPE, France

Stiglitz, J., \& Weiss, A. (1981). Credit rationing with imperfect information. American Economic Review, 71, 393-410

Uchida, H., \& Tsutsui, Y. (2005). Has competition in the Japanese banking sector improved? Journal of Banking and Finance, 29, 419-439

Uhde, A., \& Heimeshoff, U. (2009). Consolidation in banking and financial stability in Europe: Empirical evidence. Journal of Banking and Finance, 33, 1299-1311

Williams, J., \& Nguyen, N. (2005). Financial liberalisation, crisis, and restructuring: A comparative study of bank performance and bank governance in South East Asia. Journal of Banking and Finance, 29, 2119-2154 


\section{Appendix.}

Table 1. Descriptive statistics

\begin{tabular}{|c|c|c|c|c|c|c|}
\hline Variables & Definition & Mean & Median & Max & Min & Std. Dev. \\
\hline$Q$ & Total earning assets (million USD) & 10580572 & 717092 & 863000000 & 40.874 & 44235815 \\
\hline$C$ & $\begin{array}{l}\text { Total expenses (million USD) } \\
\text { Total deposit and short term funding (million }\end{array}$ & 562126 & 56354 & 43603212 & 0.810 & 2070488 \\
\hline$D$ & USD) & 9576041 & 682700 & 804000000 & 7 & 39528240 \\
\hline$R$ & Total revenue (million USD) & 591999 & 63988 & 39037317 & 1.191 & 2102181 \\
\hline$W$ & Total operating expenses to total assets & 0.5706 & 0.0211 & 24.7477 & 0.0000 & 2.3346 \\
\hline$R$ & Ratio of interest expenses to total deposits & 0.0527 & 0.0295 & 9.3901 & 0.0001 & 0.3212 \\
\hline$P$ & Ratio of total revenue to total earning assets & 0.0859 & 0.0599 & 26.5119 & 0.0001 & 0.4661 \\
\hline$O P L$ & Ratio of operating expenses to total loans & 0.0525 & 0.0369 & 0.3262 & 0.0112 & 0.0443 \\
\hline$R O A A$ & Return on average assets & 0.0081 & 0.0087 & 0.7132 & -0.5922 & 0.0378 \\
\hline$E Q T A$ & $\begin{array}{l}\text { Ratio of equity to total asset } \\
\text { Standard deviation of } R O A \text { from three-year }\end{array}$ & 0.0832 & 0.0548 & 0.9988 & -0.6322 & 0.1074 \\
\hline$S D R O A$ & rolling window & 0.0153 & 0.0049 & 0.7311 & 0.0003 & 0.0467 \\
\hline$Z R O A$ & Z-score based on $R O A$ & 41.7830 & 23.4620 & 341.5850 & -5.8090 & 54.9370 \\
\hline$R O A E$ & $\begin{array}{l}\text { Return on average equity } \\
\text { Standard deviation of } R O E \text { from three-year }\end{array}$ & 0.0831 & 0.1102 & 9.6712 & -7.2452 & 0.4466 \\
\hline SDROE & rolling window & 0.0559 & 0.0354 & 0.6950 & 0.0001 & 0.0690 \\
\hline ZROE & Z-score based on $R O E$ & 49.4890 & 30.9390 & 387.0560 & -6.5160 & 58.7830 \\
\hline$C A R$ & Ratio of total capital to risk-weighted assets & 0.1756 & 0.1250 & 0.9929 & 0.0008 & 0.1569 \\
\hline EQTA & Ratio of total equity to total assets & 0.0746 & 0.0487 & 0.9987 & -0.6321 & 0.1041 \\
\hline$L D R$ & Ratio of total loans to total deposits & 0.6587 & 0.6771 & 1.3803 & 0.0001 & 0.2103 \\
\hline$L L R$ & Ratio of loan loss reserves to total loans & 0.0598 & 0.0344 & 1.0000 & 0.0010 & 0.0094 \\
\hline$L O A N G$ & Annual loan growth & 0.2704 & 0.1156 & 6.9765 & -0.9650 & 0.8969 \\
\hline OVERHEAD & Ratio of operating expenses to total revenue & 0.4656 & 0.3531 & 45.7500 & 0.0003 & 1.2268 \\
\hline SIZE & Logarithm of total average assets & 13.1690 & 13.6090 & 20.6610 & 3.8640 & 3.1690 \\
\hline$I N F$ & Annual inflation rate & 0.0358 & 0.0305 & 0.2075 & -0.0395 & 0.0414 \\
\hline$G D P G$ & Annual real gross domestic product growth & 0.0064 & 0.0063 & 0.1140 & -0.0022 & 0.0027 \\
\hline$R L A W$ & $\begin{array}{l}\text { Rule of law index from Kaufman et al (2008) } \\
\text { Economic Freedom index from Heritage }\end{array}$ & 0.0387 & 0.0275 & 0.1577 & 0 & 0.0355 \\
\hline ECOFREE & Foundation & 60.1197 & 55.2000 & 90 & 42 & 11.4480 \\
\hline STOCK & Ratio of stock market capitalisation to GDP & 0.8313 & 0.4047 & 5.0050 & 0.0045 & 0.9903 \\
\hline
\end{tabular}


Table 2. The Lerner index in the Asian banking industry.

\begin{tabular}{ccccccc}
\hline & \multicolumn{7}{c}{ LERNER } \\
\cline { 2 - 7 } & China & Hong Kong & Indonesia & India & South Korea & Sri Lanka \\
\hline 2001 & 0.570440 & 0.428638 & 0.504237 & -0.143449 & 0.395923 & 0.599729 \\
2002 & -1.560907 & 0.900392 & 0.489753 & -0.118262 & 0.273264 & 0.741071 \\
2003 & -0.999889 & 0.935591 & 0.60836 & -0.02357 & 0.410607 & 0.874385 \\
2004 & 0.869676 & 0.70721 & 0.76211 & 0.000143 & 0.48544 & 0.915859 \\
2005 & 0.822145 & 0.43478 & 0.730938 & -0.026172 & 0.492796 & 0.859094 \\
2006 & 0.797429 & 0.285657 & 0.688297 & -0.075694 & 0.475937 & 0.813794 \\
2007 & 0.790910 & 0.366164 & 0.75164 & -0.100164 & 0.357278 & 0.704037 \\
\hline & & & \multicolumn{2}{c}{$\boldsymbol{E R N E R}$} & & \\
\hline 2001 & 0.712439 & 0.513135 & 0.571413 & 0.523875 & 0.155124 & 0.152861 \\
2002 & 0.742263 & 0.635231 & 0.534409 & 0.498261 & 0.222008 & 0.018305 \\
2003 & 0.75319 & 0.732586 & 0.641901 & 0.566692 & 0.271306 & -0.192593 \\
2004 & 0.766969 & 0.545519 & 0.709296 & 0.721333 & 0.359072 & -0.051874 \\
2005 & 0.775379 & 0.619123 & 0.666741 & 0.807386 & 0.318770 & 0.135218 \\
2006 & 0.738516 & 0.638452 & 0.604942 & 0.761431 & 0.350857 & 0.137389 \\
2007 & 0.716482 & 0.669991 & 0.600564 & 0.724995 & 0.334961 & 0.141521 \\
\hline
\end{tabular}

Source: Authors' calculation

Notes: The Lerner index is calculated using the new industrial organisation approach following Uhida and Tsutsui (2005). A higher (lower) Lerner index is associated with an increase (decrease) in market power. Moreover, higher market power in the banking industry is associated with lower bank competition. 
Table 3. The first-stage regression between instrumental variables and market power in the banking industry.

\begin{tabular}{ll}
\hline \multirow{2}{*}{ Explanatory variables } & LERNER \\
\cline { 2 - 2 } ECOFREE & $0.0196^{* * * *}$ \\
& $(13.39)$ \\
RLAW & $-0.346^{* * *}$ \\
& $(-15.53)$ \\
STOCK & $0.0503^{* * *}$ \\
& $(3.459)$ \\
GDPG & 0.0041 \\
& $(1.202)$ \\
INF & $1.433^{* * *}$ \\
& $(5.402)$ \\
LDR & $0.1314 * * *$ \\
& $(3.699)$ \\
LLR & 0.0387 \\
& $(0.3564)$ \\
LOANG & $0.0886^{* * *}$ \\
& $(5.622)$ \\
OVERHEAD & $0.1947 * * *$ \\
& $(5.35)$ \\
SIZE & 0.0022 \\
& $(0.6967)$ \\
\hline R-square & \\
Number of observations & 0.22 \\
\hline & 2302 \\
\hline
\end{tabular}

Notes: The dependent variable is the Lerner index (LERNER). Instruments consist of ECOFREE, RLAW, and STOCK. ECOFREE is the Economic Freedom index obtained from Heritage Foundation. RLAW is the Rule of Law index obtained from Kaufmann et al (2008). STOCK is the ratio of stock market capitalization to GDP obtained from Beck and Demirgüç-Kunt (2009). LERNER is the market power index calculated from the new industrial organization approach following Uchida and Tsutsui (2005). GDPG is the real gross domestic product growth rate. $I N F$ is the inflation rate. $L D R$ is the ratio of total loans to total deposits. $L L R$ is the ratio of loan loss reserves to total loans. $L O A N G$ is the annual loan growth rate. SIZE is the logarithm of total average assets. OVERHEAD is the ratio of operating expenses to total revenue. A constant is included but not reported. The model is estimated using the Ordinary Least Squares method. The $t$-statistic values are reported in parentheses. $(* * *)$ indicates significance at the $1 \%$ level, while $(* *)$ and $(*)$ indicate significance at the $5 \%$ and $10 \%$ levels, respectively. 
Table 4. The nexus between market power in banking and financial stability.

\begin{tabular}{|c|c|c|c|c|c|c|c|c|c|c|c|c|}
\hline \multirow[b]{2}{*}{ Explanatory variables } & \multicolumn{2}{|c|}{ SDROA } & \multicolumn{2}{|c|}{ SDROE } & \multicolumn{2}{|c|}{ ZROA } & \multicolumn{2}{|c|}{ ZROE } & \multicolumn{2}{|c|}{$E Q T A$} & \multicolumn{2}{|c|}{$C A R$} \\
\hline & $F E$ & $G M M$ & $F E$ & $G M M$ & $F E$ & $G M M$ & $F E$ & $G M M$ & $F E$ & $G M M$ & $F E$ & $G M M$ \\
\hline LERNER & $\begin{array}{l}0.00095 * * \\
(2.0002)\end{array}$ & $\begin{array}{l}0.0022 \\
(0.5925)\end{array}$ & $\begin{array}{l}0.0268 * * * \\
(3.139)\end{array}$ & $\begin{array}{l}0.031 * \\
(0.4759)\end{array}$ & $\begin{array}{l}-8.624 * \\
(-1.944)\end{array}$ & $\begin{array}{l}-147.1 * * * \\
(-3.317)\end{array}$ & $\begin{array}{l}-14.766 * * \\
(-2.886)\end{array}$ & $\begin{array}{l}-203.8 * * * \\
(-4.135)\end{array}$ & $\begin{array}{l}0.0075^{* *} \\
(2.311)\end{array}$ & $\begin{array}{l}-0.0428 \\
(-1.473)\end{array}$ & $\begin{array}{l}0.0043 \\
(0.6626)\end{array}$ & $\begin{array}{l}0.1466^{* * *} \\
(2.309)\end{array}$ \\
\hline$G D P G$ & $\begin{array}{l}0.00913 \\
(1.319)\end{array}$ & $\begin{array}{l}0.0906 \text { *** } \\
(6.725)\end{array}$ & $\begin{array}{l}1.961 * * * \\
(9.775)\end{array}$ & $\begin{array}{l}1.965 * * * \\
(8.019)\end{array}$ & $\begin{array}{l}-129.21 \\
(-1.189)\end{array}$ & $\begin{array}{l}-360.3 * * \\
(-2.271)\end{array}$ & $\begin{array}{l}-251.09 * * \\
(-2.025)\end{array}$ & $\begin{array}{l}-565.3 * * * \\
(-3.41)\end{array}$ & $\begin{array}{l}0.107 \\
(1.333)\end{array}$ & $\begin{array}{l}0.0234 \\
(0.2253)\end{array}$ & $\begin{array}{l}-0.1141 \\
(-0.8105)\end{array}$ & $\begin{array}{l}0.1576 \\
(0.8569)\end{array}$ \\
\hline$I N F$ & $\begin{array}{l}0.0091 \\
(1.319)\end{array}$ & $\begin{array}{l}0.0093 \\
(1.334)\end{array}$ & $\begin{array}{l}0.0888 \\
(0.4956)\end{array}$ & $\begin{array}{l}0.2238 * \\
(1.761)\end{array}$ & $\begin{array}{l}-4.601 \\
(-0.0722)\end{array}$ & $\begin{array}{l}-17.016 \\
(-0.2062)\end{array}$ & $\begin{array}{l}4.385 \\
(0.0602)\end{array}$ & $\begin{array}{l}-14.357 \\
(-0.1345)\end{array}$ & $\begin{array}{l}0.054 \\
(1.157)\end{array}$ & $\begin{array}{l}0.0469 \\
(0.9679)\end{array}$ & $\begin{array}{l}0.0479 \\
(0.5683)\end{array}$ & $\begin{array}{l}0.0519 \\
(0.4477)\end{array}$ \\
\hline$L D R$ & $\begin{array}{l}-0.005 * * * \\
(-3.766)\end{array}$ & $\begin{array}{l}-0.005^{* * *} \\
(-3.339)\end{array}$ & $\begin{array}{l}-0.150 * * * \\
(-6.866)\end{array}$ & $\begin{array}{l}-0.141 * * * \\
(-5.689)\end{array}$ & $\begin{array}{l}22.88 * * \\
(1.981)\end{array}$ & $\begin{array}{l}3.169 \\
(0.1955)\end{array}$ & $\begin{array}{l}36.238 * * * \\
(2.717)\end{array}$ & $\begin{array}{l}7.501 \\
(0.3671)\end{array}$ & $\begin{array}{l}0.0859 * * * \\
(10.051)\end{array}$ & $\begin{array}{l}0.0786 \text { *** } \\
(5.17)\end{array}$ & $\begin{array}{l}-0.033^{* *} \\
(-2.022)\end{array}$ & $\begin{array}{l}-0.0195 \\
(-0.6507)\end{array}$ \\
\hline$L L R$ & $\begin{array}{l}0.0082 * * \\
(2.551)\end{array}$ & $\begin{array}{l}0.0071 * \\
(1.596)\end{array}$ & $\begin{array}{l}-0.1011 \\
(-0.5759)\end{array}$ & $\begin{array}{l}-0.1568 * * \\
(-2.019)\end{array}$ & $\begin{array}{l}-91.85 * * * \\
(-3.258)\end{array}$ & $\begin{array}{l}20.987 \\
(0.4103)\end{array}$ & $\begin{array}{l}-33.41 \\
(-1.038)\end{array}$ & $\begin{array}{l}114.57 * * \\
(2.247)\end{array}$ & $\begin{array}{l}-0.255^{* * *} \\
(-12.247)\end{array}$ & $\begin{array}{l}-0.2128 * * \\
(-2.157)\end{array}$ & $\begin{array}{l}0.1746^{* * * *} \\
(3.182)\end{array}$ & $\begin{array}{l}0.0687 \\
(0.6428)\end{array}$ \\
\hline$L O A N G$ & $\begin{array}{l}-0.000182 \\
(-0.5533)\end{array}$ & $\begin{array}{l}-0.00035 \\
(-0.5913)\end{array}$ & $\begin{array}{l}0.0019 \\
(0.3951)\end{array}$ & $\begin{array}{l}-0.000392 \\
(-0.0378)\end{array}$ & $\begin{array}{l}-6.813 * * \\
(-2.276)\end{array}$ & $\begin{array}{l}11.229 \\
(1.623)\end{array}$ & $\begin{array}{l}-1.822 \\
(-0.533)\end{array}$ & $\begin{array}{l}21.818 * * \\
(2.438)\end{array}$ & $\begin{array}{l}-0.014 * * * \\
(-6.116)\end{array}$ & $\begin{array}{l}-0.0071 \\
(-1.414)\end{array}$ & $\begin{array}{l}-0.036 * * * \\
(-8.218)\end{array}$ & $\begin{array}{l}-0.047 * * * \\
(-3.494)\end{array}$ \\
\hline OVERHEAD & $\begin{array}{l}0.0073 \text { *** } \\
(7.374)\end{array}$ & $\begin{array}{l}0.0073 * * * \\
(7.301)\end{array}$ & $\begin{array}{l}0.0857 * * * \\
(2.087)\end{array}$ & $\begin{array}{l}0.1162 * * * \\
(6.187)\end{array}$ & $\begin{array}{l}-32.85 * * * \\
(-3.648)\end{array}$ & $\begin{array}{l}-31.07 * * * \\
(-2.661)\end{array}$ & $\begin{array}{l}-28.42 * * * \\
(-2.779)\end{array}$ & $\begin{array}{l}-26.548 * * \\
(-2.188)\end{array}$ & $\begin{array}{l}-0.0011 \\
(-0.1714)\end{array}$ & $\begin{array}{l}8.33 \mathrm{E}-05 \\
(0.0097)\end{array}$ & $\begin{array}{l}-0.038 * * * \\
(-3.249)\end{array}$ & $\begin{array}{l}-0.039 * * * \\
(-2.906)\end{array}$ \\
\hline SIZE & $\begin{array}{l}-0.0008 * * * \\
(-4.414)\end{array}$ & $\begin{array}{l}-0.001 * * * \\
(-2.809)\end{array}$ & $\begin{array}{l}-0.019 * * * \\
(-12.122)\end{array}$ & $\begin{array}{l}-0.018 * * * \\
(-3.355)\end{array}$ & $\begin{array}{l}1.5901 \\
(1.013)\end{array}$ & $\begin{array}{l}10.965 * * * \\
(3.042)\end{array}$ & $\begin{array}{l}6.082 * * * \\
(3.402)\end{array}$ & $\begin{array}{l}18.547 * * * \\
(4.395)\end{array}$ & $\begin{array}{l}-0.0014 \\
(-1.227)\end{array}$ & $\begin{array}{l}0.002 \\
(0.703)\end{array}$ & $\begin{array}{l}-0.00025 \\
(-0.089)\end{array}$ & $\begin{array}{l}-0.0104 * \\
(-1.658)\end{array}$ \\
\hline R-square & 0.5 & 0.5 & 0.45 & 0.47 & 0.32 & 0.15 & 0.24 & 0.1 & 0.79 & 0.76 & 0.79 & 0.71 \\
\hline Hausman test & $46.121 * * *$ & NA & $61.699 * * *$ & NA & $35.071 * * *$ & NA & $39.231 * * *$ & NA & $404.52 * * *$ & NA & $203.42 * * *$ & NA \\
\hline J-statistics & NA & 33.37 & NA & 44.31 & NA & 5.3 & NA & 6.11 & NA & 2.62 & NA & 0.69 \\
\hline Number of observations & 1983 & 1983 & 1978 & 1978 & 1935 & 1935 & 1937 & 1937 & 1992 & 1992 & 1584 & 1584 \\
\hline
\end{tabular}

Notes: SDROA (SDROE) is the standard deviation of return on average assets (return on average equity) calculated from a three-period rolling window. ZROA (ZROE) is the Z-score index based on return on average assets (return on average equity). LERNER is the Lerner index capturing the degree of bank competition. GDPG is the real gross domestic product growth rate. $I N F$ is the inflation rate. $L D R$ is the ratio of total loans to total deposits. $L L R$ is the ratio of loan loss reserves to total loans. $L O A N G$ is the annual loan growth rate. OVERHEAD is the ratio of operating expenses to total assets. SIZE is the logarithm of total average assets. Estimations are carried out using the Panel Least Squares with individual and time fixed-effects (FE), as well as using the Generalized Method of Moment (GMM) with individual and time fixed-effects. For those using the GMM, LERNER is instrumented with the Economic Freedom index (ECOFREE), the Rule of Law index (RLAW) and the ratio of stock market capitalization to GDP $(S T O C K)$. Hausman test for random effects is provided, as well as J-statistic for over identification condition. The $t$-statistics values are in parentheses. A constant is included but not reported. 
Table 5. The influence of economic growth on the nexus between market power in banking and financial stability.

\begin{tabular}{|c|c|c|c|c|c|c|c|c|c|c|c|c|}
\hline \multirow[b]{2}{*}{ Explanatory variables } & \multicolumn{2}{|c|}{ SDROA } & \multicolumn{2}{|c|}{ SDROE } & \multicolumn{2}{|c|}{ ZROA } & \multicolumn{2}{|c|}{ ZROE } & \multicolumn{2}{|c|}{ EQTA } & \multicolumn{2}{|c|}{$C A R$} \\
\hline & $F E$ & $G M M$ & $F E$ & $G M M$ & $F E$ & $G M M$ & $F E$ & $G M M$ & $F E$ & $G M M$ & $F E$ & $G M M$ \\
\hline LERNER & $\begin{array}{l}0.0184 * * * \\
(4.175)\end{array}$ & $\begin{array}{l}0.0514 \\
(1.496)\end{array}$ & $\begin{array}{l}0.2762 * * * \\
(4.078)\end{array}$ & $\begin{array}{l}1.435 * * \\
(2.421)\end{array}$ & $\begin{array}{l}-52.67 * * * \\
(-2.612)\end{array}$ & $\begin{array}{l}-400.5 * * * \\
(-3.753)\end{array}$ & $\begin{array}{l}-51.574 * * \\
(-2.396)\end{array}$ & $\begin{array}{l}-510.6^{* * * *} \\
(-4.491)\end{array}$ & $\begin{array}{l}-0.0366 * * \\
(-2.459)\end{array}$ & $\begin{array}{l}-0.1072 \\
(-1.348)\end{array}$ & $\begin{array}{l}0.0737 * * * \\
(2.72)\end{array}$ & $\begin{array}{l}0.2203 * * \\
(2.249)\end{array}$ \\
\hline$L E R N E R * G D P G$ & $\begin{array}{l}-0.002 * * * \\
(-3.939)\end{array}$ & $\begin{array}{l}-0.0101 * \\
(-1.956)\end{array}$ & $\begin{array}{l}-0.024 * * * \\
(-3.629)\end{array}$ & $\begin{array}{l}-0.2059 * * \\
(-2.439)\end{array}$ & $\begin{array}{l}4.445 * * \\
(2.239)\end{array}$ & $\begin{array}{l}43.777 * * \\
(2.557)\end{array}$ & $\begin{array}{l}3.72 * \\
(1.762)\end{array}$ & $\begin{array}{l}53.302 * * * \\
(2.957)\end{array}$ & $\begin{array}{l}0.0044 * * * \\
(3.033)\end{array}$ & $\begin{array}{l}0.011 \\
(0.9156)\end{array}$ & $\begin{array}{l}-0.007 * * * \\
(-2.638)\end{array}$ & $\begin{array}{l}-0.015 \\
(-0.8571)\end{array}$ \\
\hline$G D P G$ & $\begin{array}{l}0.2714 * * * \\
(4.779)\end{array}$ & $\begin{array}{l}0.4862 * * * \\
(2.959)\end{array}$ & $\begin{array}{l}3.876 * * * \\
(4.301)\end{array}$ & $\begin{array}{l}9.319 * * * \\
(3.475)\end{array}$ & $\begin{array}{l}-289.05^{* *} \\
(-2.226)\end{array}$ & $\begin{array}{l}-1633 * * * \\
(-3.155)\end{array}$ & $\begin{array}{l}-383.4 * * * \\
(-2.698)\end{array}$ & $\begin{array}{l}-2094 * * * \\
(-3.862)\end{array}$ & $\begin{array}{l}-0.0526 \\
(-0.5429)\end{array}$ & $\begin{array}{l}-0.2983 \\
(-0.8073)\end{array}$ & $\begin{array}{l}0.1062 \\
(0.6501)\end{array}$ & $\begin{array}{l}0.4935 \\
(1.154)\end{array}$ \\
\hline$I N F$ & $\begin{array}{l}0.0302 \\
(1.184)\end{array}$ & $\begin{array}{l}0.0392 \\
(1.301)\end{array}$ & $\begin{array}{l}0.3101 \\
(0.5993)\end{array}$ & $\begin{array}{l}0.5468 \\
(0.934)\end{array}$ & $\begin{array}{l}-12.669 \\
(-0.1989)\end{array}$ & $\begin{array}{l}-80.312 \\
(-1.035)\end{array}$ & $\begin{array}{l}-2.115 \\
(-0.0271)\end{array}$ & $\begin{array}{l}-85.619 \\
(-0.969)\end{array}$ & $\begin{array}{l}0.0464 \\
(0.9946)\end{array}$ & $\begin{array}{l}0.0344 \\
(0.4379)\end{array}$ & $\begin{array}{l}0.0519 \\
(0.6172)\end{array}$ & $\begin{array}{l}0.0585 \\
(0.6644)\end{array}$ \\
\hline$L D R$ & $\begin{array}{l}-0.027 * * * \\
(-3.815)\end{array}$ & $\begin{array}{l}-0.041 * * * \\
(-3.743)\end{array}$ & $\begin{array}{l}-0.278 * * * \\
(-3.227)\end{array}$ & $\begin{array}{l}-0.523 * * * \\
(-3.401)\end{array}$ & $\begin{array}{l}26.493 * * \\
(2.275)\end{array}$ & $\begin{array}{l}64.42 * * \\
(2.303)\end{array}$ & $\begin{array}{l}39.511 \text { *** } \\
(2.785)\end{array}$ & $\begin{array}{l}87.933 * * * \\
(2.739)\end{array}$ & $\begin{array}{l}0.0896 * * * \\
(10.407)\end{array}$ & $\begin{array}{l}0.0944 * * * \\
(5.146)\end{array}$ & $\begin{array}{l}-0.0399 * * \\
(-2.417)\end{array}$ & $\begin{array}{l}-0.0424 \\
(-1.326)\end{array}$ \\
\hline$L L R$ & $\begin{array}{l}-0.0245 \\
(-1.374)\end{array}$ & $\begin{array}{l}0.0241 \\
(0.7693)\end{array}$ & $\begin{array}{l}-0.18303 \\
(-0.8067)\end{array}$ & $\begin{array}{l}0.5327 \\
(1.231)\end{array}$ & $\begin{array}{l}-96.45^{* * *} \\
(-3.417)\end{array}$ & $\begin{array}{l}-171.29 * \\
(-1.948)\end{array}$ & $\begin{array}{l}-37.46 \\
(-1.312)\end{array}$ & $\begin{array}{l}-116.15 \\
-3.145\end{array}$ & $\begin{array}{l}-0.259 * * * \\
(-12.463)\end{array}$ & $\begin{array}{l}-0.2621 \\
(-1.303)\end{array}$ & $\begin{array}{l}0.1769 * * * \\
(3.231)\end{array}$ & $\begin{array}{l}0.1337 \\
(1.323)\end{array}$ \\
\hline$L O A N G$ & $\begin{array}{l}0.0019 \\
(1.484)\end{array}$ & $\begin{array}{l}0.0079 * * \\
(2.169)\end{array}$ & $\begin{array}{l}0.0126 \\
(0.8649)\end{array}$ & $\begin{array}{l}0.0863 * \\
(1.851)\end{array}$ & $\begin{array}{l}-6.606 * * \\
(-2.208)\end{array}$ & $\begin{array}{l}-10.218 \\
(-0.9816)\end{array}$ & $\begin{array}{l}-1.639 \\
(-0.6023)\end{array}$ & $\begin{array}{l}-0.2866 \\
(-1.238)\end{array}$ & $\begin{array}{l}-0.013 * * * \\
(-6.029)\end{array}$ & $\begin{array}{l}-0.0124 * \\
(-1.807)\end{array}$ & $\begin{array}{l}-0.037 * * * \\
(-8.326)\end{array}$ & $\begin{array}{l}-0.042 * * * \\
(-4.841)\end{array}$ \\
\hline OVERHEAD & $\begin{array}{l}0.0024 \\
(0.6932)\end{array}$ & $\begin{array}{l}-0.0027 \\
(-0.5171)\end{array}$ & $\begin{array}{l}0.1521 * \\
(1.671)\end{array}$ & $\begin{array}{l}0.0296 \\
(0.2556)\end{array}$ & $\begin{array}{l}-29.49 * * * \\
(-3.236)\end{array}$ & $\begin{array}{l}-0.3674 \\
(-0.0231)\end{array}$ & $\begin{array}{l}-25.58 * * * \\
(-2.771)\end{array}$ & $\begin{array}{l}11.975 \\
(0.6783)\end{array}$ & $\begin{array}{l}0.0022 \\
(0.3281)\end{array}$ & $\begin{array}{l}0.0074 \\
(0.4222)\end{array}$ & $\begin{array}{l}-0.043 * * * \\
(-3.598)\end{array}$ & $\begin{array}{l}-0.048 * * * \\
(-2.907)\end{array}$ \\
\hline SIZE & $\begin{array}{l}-0.002 * * * \\
(-4.209)\end{array}$ & $\begin{array}{l}-0.00034 \\
(-0.3008)\end{array}$ & $\begin{array}{l}-0.038 * * * \\
(-3.604)\end{array}$ & $\begin{array}{l}-0.0274 \\
(-1.513)\end{array}$ & $\begin{array}{l}2.361 \\
(1.471)\end{array}$ & $\begin{array}{l}6.348^{*} \\
(1.723)\end{array}$ & $\begin{array}{l}6.718 * * * \\
(2.792)\end{array}$ & $\begin{array}{l}13.118 * * * \\
(3.186)\end{array}$ & $\begin{array}{l}-0.00062 \\
(-0.5404)\end{array}$ & $\begin{array}{l}0.00084 \\
(0.4165)\end{array}$ & $\begin{array}{l}-0.0017 \\
(-0.5925)\end{array}$ & $\begin{array}{l}-0.0078 \\
(-1.459)\end{array}$ \\
\hline R-square & 0.34 & 0.35 & 0.43 & 0.29 & 0.32 & 0.32 & 0.24 & 0.23 & 0.79 & 0.79 & 0.79 & 0.78 \\
\hline Hausman test & $133.34 * * *$ & NA & $44.57 * * *$ & NA & $35.04 * * *$ & NA & $38.753 * * *$ & NA & $473.03 * * *$ & NA & $189.89 * * *$ & NA \\
\hline J-statistic & NA & 6.67 & NA & 10.18 & NA & 0.14 & NA & 0.0102 & NA & 2.04 & NA & 0.18 \\
\hline Number of observations & 1983 & 1983 & 1978 & 1978 & 1935 & 1935 & 1937 & 1937 & 1992 & 1992 & 1584 & 1584 \\
\hline
\end{tabular}

Notes: $S D R O A$ (SDROE) is the standard deviation of return on average assets (return on average equity) calculated from a three-period rolling window. $Z R O A$ ( $Z R O E$ ) is the $\mathrm{Z}$-score index based on return on average assets (return on average equity). LERNER is the Lerner index capturing the degree of bank competition. GDPG is the real gross domestic product growth rate. INF is the inflation rate. $L D R$ is the ratio of total loans to total deposits. $L L R$ is the ratio of loan loss reserves to total loans. $L O A N G$ is the annual loan growth rate. OVERHEAD is the ratio of operating expenses to total assets. SIZE is the logarithm of total average assets. Estimations are carried out using the Panel Least Squares with individual and time fixed-effects (FE), as well as using the Generalized Method of Moment (GMM) with individual and time fixed-effects. For those using the GMM, LERNER is instrumented with the Economic Freedom index (ECOFREE), the Rule of Law index (RLAW) and the ratio of stock market capitalization to GDP $(S T O C K)$. Hausman test for random effects is provided, as well as $J$-statistic for over identification condition. The $t$-statistics values are in parentheses. A constant is included but not reported. 